[CONTRIBUTION FROM THE LABORATORY OF THE LOUISIANA AGRICULTURAL, EXPERIMENT STATION.]

\title{
A CONTRIBUTION TO THE CHEMISTRY OF RICE OIL.
}

\author{
By C. A. Bronve, JR. \\ Received January a, zọos.
}

I. THE CHEMICAL AND PHYSICAL CONTENTS OF RICE OIL,

Bur very little attention has been paid thus far to the chemistry of rice oil, notwithstanding the very extensive use of rice as a food product. The only data, which the writer has been able to find, is a report by Smetham ${ }^{1}$ upon an oil obtained from Rangoon rice-meal by hydraulic pressure, the meal containing about i 5 per cent. oil. The oil, as thus expressed, had a dirty green color, and was partly solid at the ordinary temperature. It appeared to be especially remarkable for the large proportion of free fatty acids present, the percentage of which ranged from 3 1.6 to 77.2. A saponification value of $I 93.2$ and an iodine absorption of 96.4 were also reported.

In connection with some investigations recently carried out at the Louisiana Experiment Station in New Orleans, upon rice and the various by-products of the rice-milling industry, some attention was paid to rice oil. A number of oil samples were examined, including the oil extracted from the rice itself, as well as that obtained from the bran or meal. The latter comprises the gluten layer and germ of the rice grain and, when unadulterated with hulls, contains nearly is per cent. oil. ${ }^{2}$

The chemical and physical constants of an oil obtained from a sample of rice brain are given in the following table:

TABLE I.-CONSTANTS OF RICE OIL.

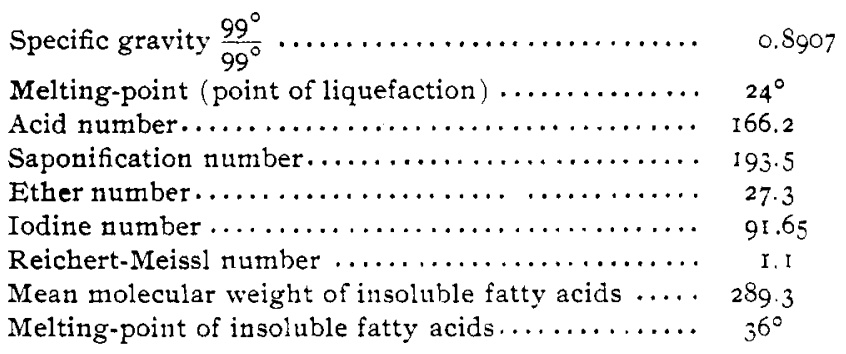

The above oil was semisolid in consistency during the winter;

$1 \mathrm{~J}$. Soc. Chem. Ind. ( $\left.1 \$_{93}\right)$, p. $8_{4} \mathrm{~s}$.

2 Calculating the rice-meal to a water-free and starch-free basis, there would be about 20 per cent. oil in the pure gluten and germ. 
it began to melt at about $24^{\circ}$, but did not become perfectly transparent until $47^{\circ}$. During the warm summer, the oil liquified partly and consisted then of a brownish-colored oil with a deposit of crystallized fats. The high acid number is noteworthy, corresponding to 83.5 per cent. of free oleic acid. In this respect the oil shares the peculiarity of those analyzed by Smetham. The fact that rice oil contains fats of high melting-point and fatty acids of high mean molecular weight would indicate the probable presence of such higher homologues as arachidic, behenic or lignoceric acids. This supposition was strengthened by the granular deposit of insoluble soaps which settled out after saponifying the oil with alcoholic potash. Further researches as to the constitution of rice oil are greatly to be desired.

\section{THE CAUSES PRODUCING ACIDITY IN RICE OIL.}

In studying the feeding value of different rice products, our attention was called to the fact that animals frequently showed a marked distaste to rice bran or meal as a food. An inquiry into the cause of this showed that in such cases the feed was very rancid and that this rancidity was due to the very acid condition of the rice oil. Experiments made upon fresh rice bran showed that the oil from the same was only slightly acid, but that upon standing any great length of time a rapid development of acidity took place in the oil, the feed at the same time becoming rancid. In large bulks the development of rancidity in rice-meal seems to be accompanied by a heating and caking of the material.

Instances of such excessive acidity as those noted for rice oil, have been observed in the case of a few other vegetable oils. Palm oil is especially characterized by a high content of free acid. Lewkowitsch" states that "even in the fresh state the proportion of fatty acids in palm oil, calculated as palmitic acid, amounts to I 2 per cent., and may in older samples reach as much as 100 per cent.-in other words, the splitting-up of the glycerides may become complete." Olive kernel oil ${ }^{2}$ and olive oil $1^{3}$ expressed from the marc also contain large quantities of free fatty acids.

It has long been a recognized fact that atmospheric oxygen, especially in the presence of light, is a very important factor in the decomposition of oils and fats. This influence would no doubt

1 Lewkowitsch: "Analysis of Oils, Fats, and waxes," 2nd edition, p. 517.

2 Benedikt : "Analyse der Fette und Wachsarten," 3 Auf., p. 458.

3 Ibid., p. 447 : see also Iewkowitsch : Loc. cit., p. 451. 
be greater with oil in a finely divided condition, as would be the case in rice meal. There is, however, another explanation possible for the decomposition of rice oil besides that of oxidation. The work of different investigators shows that in many cases a decomposition of vegetable oil is produced by means of a fat-splitting enzyme-lipase. Reynolds Green ${ }^{1}$ has reported the presence of lipase in the germinating seeds of the castor oil plant and Sigmund $^{2}$ has demonstrated its existence in both the resting and germinating seeds of rape, poppy, hemp, flax and maize. The crushed seeds of these plants produced in all cases a development of acidity in neutral emulsions of oil. That the hydrolysis of the oil was due to an enzyme, was shown by the fact that control experiments, in which the enzymes had been killed by boiling, developed no acidity. The high degree of acidity in palm oil and olive-marc oil has also been attributed to enzyme action. ${ }^{3}$

LIPASE IN RICE BRAN.

An aqueous extract of rice bran was prepared by allowing 20 grams of the material to soak in $100 \mathrm{cc}$. of cold water for several hours. $25 \mathrm{cc}$. of the clear filtered extract, when mixed with $5 \mathrm{cc}$. of commercial hydrogen peroxide, produced a rapid evolution of oxygen, the quantity of this exceeding Ioo cc. within a few minutes. The bran extract also produced with tincture of guaiac a strong blue coloration, after adding a few drops of hydrogen peroxide. Both of the above reactions failed with bran extract which had been boiled. Many plant juices and extracts cause a catalytic decomposition of hydrogen peroxide, and give the blue reaction with guaiac and the peroxide; these properties have been thought by some investigators to belong to nearly all enzymes, though Loew ${ }^{4}$ considers them characteristic of two special ferments, catalase and peroxidase. Without entering into a discussion of this question, we may say that the above reactions, while showing that enzymes are present in rice, do not throw much light upon their specific nature or functions.

To determine whether or not a lipatic ferment is present in rice bran, use was made of the well-known emulsion test. Twenty

1 Reynolds Green : "Soluble Ferments and Fermentation," p. 227.

a Sigmund: "Ueber fettspaltende Fermente im Pflanzenteiche," Monatsh. Chem. (Vienna), 11, 272 (1890).

3 Lewkowitsch: "Notes on Fat-Splitting Enzymes," J. Soc. Chem. Ind. (I903), p. 6g.

4 Loew: "Catalase, a New Enzyme of General Occurrence," Report No. 68. C. S. Dept. of Agt.; see also Report No. 65 by same author, "Physiological Studies of Conn. Leaf Tobacco," pp. 30-34. 
cc. of the clear bran extract were thoroughly shaken up with an equal volume of a thick emulsion of castor oil, and the mixture rendered faintly alkaline to litmus solution. After standing at the laboratory temperature for twenty-four hours, the solution began to turn pink, and in two days had become a deep red. A similar experiment, conducted with extract which had been previously boiled, remained alkaline; likewise, blanks of the unboiled extract to which no emulsion had been added, so that the development of acid could only come from the action upon the oil of a fat-splitting enzyme. To prevent the formation of acid products by bacteria, 0.25 per cent. of potassium cyanide was used in each experiment as a germicide. The cyanide may have exerted an inhibitive effect upon the activity of the enzyme, yet the necessity of using an antiseptic agent in such tests is imperative, as was shown by the fact that, when no cyanide was employed, neutral solutions of bran extract became acid to litmus in a few hours. After standing a week, the acid emulsion in the above experiment was shaken out with ether, and the ethereal solution filtered and evaporated to dryness. The oil thus obtained had an acid number of 29.7 , which would indicate that about 16 per cent. of the oil had undergone hydrolysis.

To determine the hydrolyzing effect of lipase upon rice oil under natural conditions, the following experiment was conducted. A sample of fresh rice bran was taken to the laboratory immediately after milling and divided into two portions. One portion was subjected to a dry heat of $90^{\circ} \mathrm{C}$ to destroy any enzymes; the other portion remained untreated. Both samples were tied up in sacks and set aside for one month. The acidity of the oil from the fresh bran (containing 14.3 per cent. oil) was determined, and also that of the oil obtained from the raw rice used in manufacturing the bran. The same determinations were also made on the oils extracted from the two samples of bran after standing one month. The results of the work are given in the following table:

TABLE II.

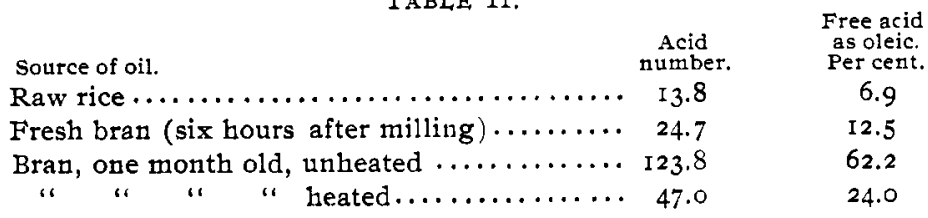

The above results show that an exceedingly rapid decomposi- 
tion of the oil in the unheated bran had taken place. In the oil of the bran, which had been heated, there was also some development of free acid, but the quantity formed was less than one-fourth that developed in the oil of the unheated sample. The experiment would indicate that while the development of acidity in rice oil may be, to a slight extent, the result of oxidation, it is to a much greater clegree the effect of a fat-splitting enzyme. ${ }^{1}$

The sample of raw rice, from which the bran used in the experiment was made, was taken from a large quantity that had been lying in storage in a New Orleans warehouse many months. The oil from the bran six hours after milling, compared with the oil from the original rice, shows an increase in free acid of 5.6 per cent. This shows that a rapid decomposition of the rice oil sets in immediately after milling, the activity of the enzyme seeming thus to depend upon an exposure of the oil-bearing tissues of the rice grain to the air. The amount of free acid in the oil within the rice grain is probably less than that indicated in Table II, as some decomposition no doubt took place during the grinding of the grain, before the extraction with ether.

The foregoing experiments have a certain practical interest, since a clestruction of the lipase at once suggests itself as a means for the prevention of rancidity in rice-meal and similar products. By subjecting the material, directly after milling, to a dry heat sufficient to destroy the enzyme, such as is done in the kiln-drying of certain feeds, the development of rancidity wonld be largely checked.

\section{THE DIGESTIBILITY OF RICE OIL.}

In connection with some feeding experiments, recently conducted at this Experiment Station, with rice bran and rice polish. the following coefficients of digestibility for rice oil were obtainerl. Two steers were used in the work.

$$
\begin{aligned}
& \text { Rice bran. Rice polish. } \\
& \text { Per cent, oil digested. Per cent. oil digested. } \\
& \text { Steer No. I.............. } 52.0 \\
& 66.0 \\
& 8 \text { I. } 2 \\
& \text { Average } \ldots \ldots \ldots \ldots \ldots \ldots \quad \frac{5.5}{54.8} \quad \overline{73.6}
\end{aligned}
$$

There are several facts which may explain the greater digesti-

1 For further particulars as to the action of lipase, see the work of Kastle and Loevenhart (Amer. Chem. J, 24, 491 (tg00)).

2 The enzyme is probably the product of at antecedent substance or zymogen, this transformation not taking place except when the seed is crushed or while it is germina. ting. (See Reynolds Green, "Soluble Ferments and Fermentation," p. 38r.) 
bility of the rice oil in the polish. In the experiment with rice polish, the steers received only about one-third the quantity of oil given in the bran experiment and may thus have been able to digest a greater percentage of oil from the ration. The bran was very coarse, containing about 30 per cent. of rice hulls; the polish was free from hulls, and contained more of the starchy part of the rice than the bran. The oil from the bran contained 83.5 per cent. free fatty acids, the oil from the polish 47.5 per cent. The conditions may, therefore, have been more favorable in the polish towards securing a more complete digestion of the oil. Individuality of the animal is seen to play an important part. Steer No. 2 digested a greater percentage of oil in both experiments, the difference in the case of the polish being especially marked.

In the bran experiment, the oil from the feed and the undigested oil from the feces were analyzed. A comparison of the two sets of constants shows very noticeable differences, and throws some light upon the changes which the rice oil undergoes during digestion.

TABIE III.-Showing EFFECT OF Digestion UpoN CoMposition of Rice OrL.

\begin{tabular}{|c|c|c|}
\hline $\begin{array}{l}\text { Constant. } \\
\text { Melting-point (point of liquefaction)... }\end{array}$ & $\begin{array}{c}\text { Oil from } \\
\text { rice bran. } \\
24^{\circ}\end{array}$ & $\begin{array}{c}\text { Oil from feces } \\
\text { of steers } \\
\text { fed on } \\
\text { rice bran. } \\
58^{\circ}\end{array}$ \\
\hline 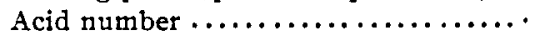 & 166.2 & $I 44.2$ \\
\hline Saponification number ............. & I93.5 & I 76.0 \\
\hline Ether number.$\ldots \ldots \ldots \ldots \ldots \ldots \ldots$ & 27.3 & 31.8 \\
\hline $\begin{array}{l}\text { Iodine number. } \ldots \ldots \ldots \ldots \ldots \ldots \ldots \ldots \ldots \\
\text { Mean molecular weight insoluble fatty }\end{array}$ & 91.65 & 27.08 \\
\hline $\begin{array}{r}\text { acids } \ldots \ldots \ldots \ldots \ldots \ldots \ldots \ldots \ldots \\
\text { Melting-point insoluble fatty acids..... }\end{array}$ & $\begin{array}{l}289.3 \\
36^{\circ}\end{array}$ & $\begin{array}{c}320.2 \\
60^{\circ}\end{array}$ \\
\hline
\end{tabular}

The oil obtained from the feces was light-colored and of waxlike consistency. The soaps obtained on saponifying this oil with alcoholic potash were marked by a low degree of solubility in alcohol. The oil extracted from the feces was no doubt contaminated tosome extent with metabolic products from the animal, such as biliary substances and fatty bodies from the intestines. Some unsaponifiable matter was present, but this was removed before determining the constants of the fatty acids. Beef-fat from the intestines, according to Mayer, ${ }^{1}$ has the following constants :

\footnotetext{
1 Wagner's Jahresberichte (1880), 844 .
} 
Melting-point $\ldots \ldots \ldots \ldots \ldots \ldots \ldots \ldots \ldots \ldots \ldots \ldots, 50^{\circ}$

Saponification number $\ldots \ldots \ldots \ldots \ldots \ldots \ldots \ldots \ldots, 196.2$

Melting-point insoluble fatty acids $\ldots \ldots \ldots \ldots \ldots \ldots, \quad 47.5^{\circ}$

Mean molecular weight insoluble fatty acids $. . \ldots \ldots \ldots, \quad 278.2$

The presence of fat, sluffed off from the walls of the intestinal tract, could not, therefore, explain the differences noted in Table III. The most satisfactory and plausible explanation of the facts is a difference in digestibility of the various constituents of the rice oil. The liquid unsaturated bodies are very largely absorbed in the process of digestion, as is shown by the marked decrease in the iodine number. The fatty acids of lowest molecular weight are also the easiest to assimilate; hence, the oil excreted in the feces consists largely of a residue of acids of high mean molecular weight and high melting-point. Reference was made, in the first section of this paper, to the probable presence in rice oil of such higher acids as arachidic, behenic, or lignoceric, anci this supposition finds support in the character of the fatty acids in the oil from the feces, these having a mean molecular weight higher even than the molecular weight of arachidic acid (312).

Stearic acid, the highest saturated fatty acid in the animal body, has a molecular weight of 284 , and saturated fatty acids of greater molecular weight than stearic are probably assimilated by the animal only to a limited extent.

In conclusion, the writer desires to express his indebtedness to Dr. IV. C. Stubbs, under whose direction the work was carried on, for advice and encouragement.

[CONTRIbUtion from BUREaU OF Chemistry, U. S. Department of Agricclture, . No. 5o. Sent by H. W. WILey.]

OLIVE OILS AND OLIVE OIL SUBSTITUTES.

BY L. M. TOLMAX AND L. S. MUNSON

Receiven July 13, 2903.

SOURCES OF THE OILS.

IN AN investigation of olive oils and their substitutes, a number of pure California and Italian olive oils were obtained and analyses of them made. The California oils were largely obtained from representative producers, with affdavits as to their purity. The Italian oils were received through agents in Italy. The collection of oils thus made contained samples from most of the oilproducing districts of both countries. 